ISSN: 2536-5339

\title{
Doktor Adaylarının Zihinsel Yetersizliği Olan Bireylerde Sporun Etkilerine Yönelik Farkındalıkları
}

\author{
Didem Gülçin KEMEÇ ${ }^{1}$ \\ Gönül TEKKURŞUN DEMIR ${ }^{2}$ \\ ${ }^{1}$ Afyon Kocatepe Üniversitesi Beden Eğitimi ve Spor Yüksekokulu, AFYON
${ }^{2}$ Gazi Üniversitesi Spor Bilimleri Fakültesi, ANKARA
${ }^{3}$ Gaziantep Üniversitesi Beden Eğitimi ve Spor Yüksekokulu, GAZIANTEP
}

Selahattin $\mathrm{KOÇ}^{3}$

Künye: Kemeç, D.G., Tekkurşun Demir, G. ve Koç, S. (2018). Doktor Adaylarının Zihinsel Yetersizliği Olan Bireylerde Sporun Etkilerine Yönelik Farkındalıkları. Gaziantep Üniversitesi Spor Bilimleri Dergisi, 3(4): 153-168.

\section{Öz}

Özel beden eğitimi ve spor aktiviteleri doğru planlandığında zihinsel yetersizliği olan çocuklar için yaşam kalitesini doğrudan etkileme gücüne sahip etkili bir mekanizmadır. Zihinsel yetersizlik ile ilgili olarak tıbbi ve eğitsel tanılama söz konusudur. İlk olarak tıbbi tanı konulmakta ve ailelere bu durumu doktorlar açıklamakta bunun yanında çeşitli yönlendirmeler yapabilmektedirler. Dolayısıyla aileyi yönlendirme gücüne sahip olan doktorların beden eğitimi ve sporla ilişkili olarak farkındalık düzeyleri önem arz etmektedir. Bu araştırma kapsamında, tıp fakültelerinde öğrenim görmekte olan doktor adaylarının zihinsel engelli bireylerde sporun etkilerine yönelik farkındalıklarının farklı değişkenlere göre incelenmesi amaçlanmıştır. Araştırma grubunu 2016-2017 akademik yılı Cumhuriyet, Gaziantep ve Marmara Üniversiteleri Tıp Fakültesinde öğrenim gören gönüllülük esası ile seçilmiş 124'ü kadın, 92'si erkek toplam 216 öğrenci oluşturmuştur. Araştırmada veri toplama aracı olarak araştırmacılar tarafından geliştirilen "Kişisel Bilgi Formu", İlhan ve Esentürk (2015) tarafından geliştirilen, "Zihinsel Engelli Bireylerde Sporun Etkilerine Yönelik Farkındalık Ölçeği (ZEBSEYFÖ)" kullanılmıştır. Verilerin değerlendirilmesinde SPSS 21 for Windows paket programı kullanılmıştır. Sosyodemografik özellikler bakımından farkındalık düzeyleri arasındaki farklılığı belirlemek amacıyla normal dağılım göstermeyen veriler için non-parametrik testlerden "MannWhitney U" ve "Kruskal-Wallis Testleri"; betimsel istatistiklerden yüzde dağılımları, aritmetik ortalama ve standart sapma değerleri kullanılmış ve anlamlılık düzeyi 0,05 olarak alınmıştır. Araştırma sonucunda doktor adaylarının yüksek düzeyde bir farkındalığa sahip oldukları belirlenmiştir. Erkek ve kadın doktor adaylarının farkındalık düzeyleri birbirine yakınlık göstermektedir. Düzenli olarak fiziksel etkinlik yapan ve engelli bir yakını bulunan doktor adaylarının farkındalıkları yüksek olsa da gruplar arasında anlamlı bir farklılığa rastlanmamıştır. Bunun yanında doktor adaylarının aldıkları lisans eğitim düzeyleri kapsamında sınıf düzeyleri arttıkça farkındalıklarının da arttığı belirlenmiştir.

Anahtar Kelime: Doktor Adayları, Zihinsel Yetersizlik, Farkındalık, Beden Eğitimi ve Spor

\section{Orijinal Makale}

Yayın Bilgileri

Gönderi Tarihi: 27.07.2018

Kabul Tarihi: 10.12.2018

Yayın Tarihi: 28.12.2018

\section{Sorumlu Yazar}

e-mail: didemkemec@gmail.com

DOI: 10.31680 /gaunjss.448576 


\section{Awareness Of Doctor Candidates Towards The Impact Of Sports On Mental Insufficient Individuals}

\begin{abstract}
Special physical education and sports activities are efficient mechanisms that have a direct impact on the life quality of mental insufficient children, when they are designed correctly. There is a matter of a medical and educational diagnosis about mental insufficiency. Firstly, a medical diagnosis is made, and the doctors explain it to the families with some guidance. Therefore, the level of awareness of doctors, who have the competency of guiding families, towards physical education and sport is important. This study aims to examine the awareness of doctor candidates, who study at the medical faculties, on the effects of sport on intellectually disabled individuals, according to some variables. The research group consists of 216 students (voluntarily chosen 124 women, 92 men) who study at the medical faculties at Cumhuriyet, Gaziantep, Marmara universities during 2016-2017 education period. "Personal Information Form" developed by researchers and "The Awareness Scale Regarding Effects of Sport on Persons with Intellectual Disabilities" developed by İlhan and Esentürk in 2015 have been used as data collection tools. SPSS 21 package program for windows has been used to examine the data. In order to determine the differences between the levels of awareness in terms of socio-demographic characteristics, MannWhitney $U$ test and Kruskal-Wallis test from non-parametric tests have been used for non-normally distributed data; from descriptive statics percentage distribution, mean and standard deviation have been used and the significance level is set to 0,05 . As a result, it has been found out that doctor candidates have a high level of awareness. The awareness levels of male and female candidates are similar. Although the doctor candidates, who exercise regularly and have a disabled relative, have a higher level of awareness, there is no significant difference between the groups. Additionally, it is seen that the awareness level of doctor candidates gets higher as the class level increases.
\end{abstract}

Keywords: Doctor Candidates, Mental Insufficiency, Awareness, Physical Education and Sports

\section{Original Article}

\section{Article Info}

Received: 27.07.2018

Accepted: 10.12 .2018

Published: 28.12.2018

Corresponding Author

e-mail: didemkemec@gmail.com

\section{Giriş}

İlkel çağlardan bu yana toplumlar kendi içinde belirli örgütlenmeler oluşturmuş ve yaşama intiyaçlarını işbirliği içerisinde karşılamaya çalışmışlardır. Bu örgütlenmeler çerçevesinde kimi yeme-içme, barınma ihtiyacını karşılarken kimileri de herhangi bir sağlık sorunu yaşandığında bu duruma bir çare arama görevini üstlenmiştir. Bugün fiziksel, zihinsel, psikolojik ve benzer bir problem durumu yaşandığında; genellikle bireylerin ilk başvurduğu kişiler doktorlardır. İstatistiksel veriler açısından toplumların doktorlara ihtiyaç duyma derecesine bakıldığında ise TÜIKK (2011) Nüfus ve Konut Araştırması sonuçlarına göre en az bir engeli olan 3 yaş ve daha üstü bireylerin Türkiye nüfusunun \%6,9'unu; Dünya Engellilik Raporu 2010 yılı tahminlerine göre de herhangi bir engel türüne maruz kalan bireylerin dünya nüfusunun \%15'ini oluşturduğu görülmektedir.

Zihinsel yetersizlik; özellikle gelişimsel dönemde ortaya çıkan uyumlu davranışlarda yetersizlik durumu olarak kabul görmektedir (Çavdar, 2011). Bir başka yönden genel zekâ fonksiyonlarının normalin altında olması durumu, "herkes gibi 
olamama" ifadesiyle farklılığın doğuşunu işaret etmektedir. Sözü edilen farklılı̆ın iyileştirilme sürecinde ise zihinsel yetersizliği olan bireylerin sağlık problemlerini minimal düzeye indirgemek ve toplumsal anlamda sosyalleşmelerini sağlamak adına en önemli mekanizmalardan biri beden eğitimi ve spordur (IIlhan ve Esentürk, 2015). İlhan (2008)'a göre sportif etkinlikler, yetersizliği olan bireylerin kaslarının güçlendirilmesi, koordinasyon, denge, esneklik, solunum ve dolaşım sistemlerinin gelişimi ve spastisiteyi önlemede önemli ölçüde fayda sağlamaktadır. Ayrıca erken yaşta yapılan yönlendirmeler sayesinde bireylerin sosyal, duygusal, fiziksel, zihinsel ve hareket gelişim özelliklerinde de ilerlemeler kaydedildiği görülmektedir. Bugün herhangi bir engele maruz kalmayan birçok insan bile doğumundan ölümüne kadar spor etkinlikleri ile yaşam kalitelerini arttırmakta, daha sağıklı olmak için bu etkinliklere devam etmektedirler. Dolayısıyla bu aşamada sportif faaliyetler bireylerin fiziksel ve psikolojik gelişimlerinin yanı sıra koruyucu hekimlik ve tedavi edici özellikleriyle de fayda sağlamaktadır (Yetim, 2011).

Farkındalık; bireylerin önce bir kavram olarak öğrenilmesi daha sonra tüm duyu organlarıyla anlamlandırılıp özümsenmesi ve bilinmesi gereken konuları öğrenerek hassasiyet göstermesi olarak ifade edilmektedir (IIhan ve Esentürk, 2015). Nazik, hoşgörülü olmak, olumlu tutum sergilemek huzuru ve sağlığı beraberinde getirmektedir. Hatta konuyla ilişkili olarak kanser ve benzeri birçok hastalığın da pozitif etkilerle en aza indirgendiği, bugün bilinen bir gerçektir. Umudu olan, kendine güvenen, gerçekle ilişki kurarak motivasyonunu arttıran, karamsarlık, çaresizlik gibi olumsuz tutumları önleme girişiminde olan kanser hastaları, baş etme mekanizmasıyla tedaviye uyumda katkı sağlamaktadırlar (Turan Kavradım ve Canlı Özer, 2014). Ayrıca hemşire vb. sağlık personelinin hastalara olan pozitif tutumları, tedavi sürecinde kaliteli bakımın sağlanmasında da etkin rol oynamaktadır. Bu bağlamda zihinsel yetersizliği olan bireylerin eğitimi, sağlığı ve rehabilitasyonu açısından toplumun, ailenin, çevrenin, büyük rolleri olan uzmanların beklenti tutum ve farkındalıkları da önemli bir yer tutmaktadır (Akbuğa ve Gürsel, 2007).

Beden eğitimi ve spor etkinlikleri, doğal ortamı içinde bulunan tüm bireyleri farkı şekillerde etkilemekte ve tüm gelişim boyutlarını desteklemektedir (IIlhan, 2008). Zihinsel yetersizliği olan çocuklar için spor aktiviteleri, en başta toplumsal ve ruhsal uyum düzeylerine yapacağı olumlu katkının yanında benlik algılarını arttırarak çevreleriyle iletişimlerini geliştirecekleri fırsatlar sağlar (Güvendi ve İlhan, 2017; Filazoğlu ve ark., 2015). 
Zihinsel yetersizlikte tıbbi tanının doktorlar tarafından konulması, özellikle ebeveynlerin çocukları ile ilgili alabilecekleri başta özel eğitim ve paralel aktivitelere yönelik öneriler noktasında bu meslek grubunu oldukça değerli kılmaktadır. Nitekim alan uzmanı doktorlar tarafından değerlendirilen çocuklar için hareketli bir yaşamın olası katkılarının yine en başta doktorlar tarafından ebeveynlere sunulması beklenmektedir. Doktor, hemşire, ya da fizyoterapist tarafından fiziksel aktiviteye yönlendirilen bu bireyler, böylece yalnızlığından, öfke, nefret gibi olumsuz duygularından sportif faaliyetlerle uzaklaşmakta; toplumsal bir rol ve statüye sahip olmaktadırlar. Bunun yanı sıra zihinsel, fiziksel ve sağlık yönünden de gelişim göstermektedirler.

Rehabilitasyonun yaşam kalitesini arttıran bir özelliğe sahip olduğu gibi spor da tüm bireylerin yaşam kalitesini arttırma niteliği taşımakta; bu anlamda sağlıklı yaşam ve sporun etkileri hakkında bireyler de bilinçlendirilmeye çalışılmaktadır. Koparan (2003)'a göre, gelişen eğitim programlarıyla; doktor, hemşire, öğretmen ve fizyoterapist gibi meslek elemanlarının, bilinçli ebeveyn profilleri oluşturma yolunda önemli rolleri vardır.

Hangi engel grubunda olursa olsun erken yaşlardan itibaren gelişimin sağlanabilmesi açısından bireylerin farklılıklarını gözlemleyecek ilk kişiler çoğunlukla en yakınında olan anne ve babalar (IIhan, 2009); yetersizlik anlamında tanıyı koyabilecek yetkin kişiler ise doktorlardır. Doktorlar yapmış oldukları incelemeler sonunda önce bireyin yetersizliği olup olmadığını, yetersizliği mevcutsa hangi türde olduğunu belirleyerek gerekli tanıyı koymakta daha sonra ise engel türü kapsamında uzmanlık alanına göre meslektaşlarına, fizyoterapist, psikiyatr, rehabilitasyon ve fiziksel aktivite gibi alanlara yöneltmektedirler. Kayıhan ve ark. (2013)'na göre de yöneltmelerle bağlantılı şekilde; yetersizliği olan bireylerin sağlık, çevre ve toplumsal düzeydeki diğer sorunların çözüme ulaşabilmesi için öncelikli olarak bireyin aile üyelerine, arkadaşlarına, soysal destek ve sağlık çalışanlarına farkındalık eğitimi verilmesi gerektiği dile getirilmektedir. Dolayısıyla aileyi yönlendirme gücüne sahip olan doktorların beden eğitimi ve sporla ilişkili olarak farkındalıkları önem arz etmektedir. Bu anlamda edinilen bilgiler ışığında çalışmanın amacı, tıp fakültesinde eğitim görmekte olan doktor adaylarının cinsiyet, sınıf, düzenli spor yapma durumu, ailede engelli birey bulunup bulunmama durumu ve bulunuyorsa engel türü değişkenlerine göre zihinsel engelli bireylerde sporun etkilerine yönelik farkındalıklarının incelenmesi olarak belirlenmiştir. 


\section{Yöntem}

Araştırmanın bu bölümünde araştırmanın modeline, evren ve örneklemine, veri toplama araçlarına, verilerin analizine ve çözümlenmesine ilişkin bilgilere yer verilmiştir.

\section{Araştırmanın Modeli}

Araştırma, nicel araştırma modellerinden tarama deseninde bir çalışmadır. Tarama deseni, çok sayıda elemandan oluşan bir evrende, evren hakkında genel bir yargıya varmak amacı ile evrenin tümü ya da ondan alınacak bir grup, örnek ya da örneklem üzerinde yapılan tarama düzenlemeleridir (Karasar, 2009).

\section{Araştırma Grubu}

Araştırma grubunu, 2016-2017 akademik yılı Cumhuriyet, Gaziantep ve Marmara Üniversiteleri Tıp Fakültesi alanında 1., 2., 3., 4., 5. ve 6. sınıfta öğrenim görmekte olan 124'ü kadın, 92'si erkek 216 öğrenci oluşturmaktadır. Araştırmacının isteğine bağlı olarak çalışma grubunda gönüllülük esas alınmış olup eksik ve yanlış kodlamalar analize dahil edilmemiştir.

\section{Veri Toplama Araçları}

Verilerin toplanması aşamasında; doktor adaylarının demografik bilgilerine ulaşmak için "Kişisel Bilgi Formu", farkındalık düzeylerini belirlemek amacıyla ise İlhan ve Esentürk (2015) tarafından geçerlilik ve güvenirliği yapılmış olan "Zihinsel Engelli Bireylerde Sporun Etkilerine Yönelik Farkındalık Ölçeği (ZEBSEYFÖ)” uygulanmıştır.

\section{Zihinsel Engelli Bireylerde Sporun Etkilerine Yönelik Farkındalık Ölçeği}

Veri toplama aracı olarak kullanılan ZEBSEYFÖ, bireyin kendisi hakkında bilgi vermesine dayanan (self-report) bir ölçme aracı olarak geliştirilmiştir. Ölçeğin orijinalinde 32 maddelik ölçeğe yönelik Croanbach Alpha değeri 0,989 olarak bildirilmiştir. Bu çalışma için yapılan Croanbach Alpha değeri ise 0,966 olarak hesaplanmıştır.

5'li likert tipinde 32 maddeden oluşan ölçeğin maddeleri, beşli dereceleme sistemine göre hazırlanmıştır. Bu beş madde; "Tamamen Katılıyorum, Katılıyorum, Kararsızım, Katılmıyorum, Hiç Katılmıyorum" şeklindedir. Maddeler olumlu ifadeler 
için sırasıyla 5, 4, 3, 2 ve 1 şeklinde puanlanırken; olumsuz ifadeler için 1, 2, 3, 4, 5 olmak üzere tersten değerlendirilmiştir. Olumsuz ifadeleri içeren sorular ise " $3,6,9$, 12, 15, 18, 21, 24, 27 ve 30" numaralı maddelerdir. En yüksek puan 160, en düşük puan ise 32'dir. Belirli aralıklardaki puanlar düşük, orta ve yüksek seviyedeki farkındalığı belirtmektedir. Dolayısıyla puanları; 32 ile 74 arasında olanlar düşük, 75 ile 117 arasında olanlar orta, 118 ile 160 arasında olanlar ise yüksek seviyede farkındalığa sahiptir.

\section{Verilerin Analizi}

Verilerin analizinde; değişkenlerin alt gruplarına ait frekans ve yüzde dağılım değerleri hesaplanmıştır. Değişkenlere normallik testi ve varyansların homojenliği için "Kolmogorov-Smirnov Testi" ve "Levene Testi" uygulanmıştır. Bu testler sonucunda farkındalık düzeyi değişkeninin normallik varsayımını sağlamadığı görülmüş ve değişkene yönelik analizlerde parametrik olmayan yöntemler kullanılmıştır.

Araştırmaya katılan öğrencilerin genel farkındalık puanlarını belirlemek için aritmetik ortalama $(\bar{x})$, standart sapma (ss), minimum (min) ve maximum (max) değerleri hesaplanmıştır. Sosyo-demografik özellikler bakımından farkındalık düzeyleri arasındaki farklılığı test etmek için "Mann-Whitney U Testi" ve "KruskalWallis Testi" kullanılmıştır. Uygulanan parametrik olmayan testlerde, merkezi limit kuramı gereğince örnek çapı büyük olan testlerde Mann-Whitney U Testi için "Z" dağııımı istatistiği, "Kruskal-Wallis Testi için "Ki-Kare" dağılımı istatistiği alınmıştır. Araştırmada kullanılan ölçeğin geçerlilik ve güvenilirliğini test etmek için "Cronbach's Alpha Testi" uygulanmış ve alpha katsayısı 0,966 olarak hesaplanmıştır. Bu sonuca göre araştırmada kullanılan ölçeğin yüksek güvenirliğe sahip olduğu saptanmıştır. Uygulanan istatistiki testlerde güven düzeyi $\alpha=.05$ olarak esas alınmış ve hipotezler $\alpha=.05$ güven düzeyinde test edilmiştir. İstatistiki analizler SPSS 21 for Windows paket programıyla yapılmıştır. 


\section{Bulgular}

Tablo 1. Araştırmaya Katılan Öğrencilerin Sosyo-Demografik Özelliklerine İlişkin Frekans Dağılımı

\begin{tabular}{|c|c|c|c|c|}
\hline Değişkenler & Alt Kategoriler & $\mathbf{N}$ & $\%$ & Toplam \\
\hline \multirow{2}{*}{ Cinsiyet } & Kadın & 124 & 57,4 & \multirow{2}{*}{216} \\
\hline & Erkek & 92 & 42,6 & \\
\hline \multirow{6}{*}{ Sinıf } & 1 & 50 & 23,1 & \multirow{6}{*}{216} \\
\hline & 2 & 38 & 17,6 & \\
\hline & 3 & 38 & 17,6 & \\
\hline & 4 & 35 & 16,2 & \\
\hline & 5 & 28 & 13,0 & \\
\hline & 6 & 27 & 12,5 & \\
\hline \multirow{2}{*}{ Düzenli Spor Yapma Durumu } & Evet & 91 & 42,1 & \multirow{2}{*}{216} \\
\hline & Hayır & 125 & 57,9 & \\
\hline \multirow{2}{*}{$\begin{array}{l}\text { Ailenizde/Akrabanızda } \\
\text { Engelli Birey Var Mı? }\end{array}$} & Evet & 18 & 8,3 & \multirow{2}{*}{216} \\
\hline & Hayır & 198 & 91,7 & \\
\hline \multirow{4}{*}{ Engel Türü } & Zihinsel Engelli & 8 & 44,4 & \multirow{4}{*}{18} \\
\hline & İşitme Engelli & & & \\
\hline & Görme Engelli & 2 & ,9 & \\
\hline & Bedensel Engelli & 8 & 3,7 & \\
\hline
\end{tabular}

Tablo 1'e göre araştırma kapsamına \%57,4'ü kadın, \%42,6'sı erkek olmak üzere toplam 216 tıp fakültesi öğrencisi katılmıştır. Öğrencilerin \%23,1'i 1.sınıf, \%17,6'sı 2.sınıf, \%17,6'sı 3.sınıf, \%16,2'si 4.sınıf, \%13'ü 5.sınıf ve \%12,5'i 6.sınıfta öğrenimlerine devam etmektedir. Araştırmaya katılan öğrencilerin \%42,1'i düzenli spor yaparken; \%57,9'u düzenli spor yapmamaktadır. Öğrencilerin \%8,3'ünün ailesinde/akrabasında engelli birey bulunurken, \%91,7'sinde engelli birey bulunmamaktadır. 
Tablo 2. Araştırmaya Katılan Öğrencilerin Demografik Değişkenlere Göre Zihinsel Engelli Bireylerde Sporun Etkilerine Yönelik Farkındalık Ölçeği Puanları

\begin{tabular}{ccccccc}
\hline Değişkenler & Seçenek & $\mathbf{N}$ & $\overline{\mathbf{x}}$ & Ss & Min. & Max. \\
\hline \multirow{3}{*}{ Cinsiyet } & Kadın & 124 & 135,52 & 23,19 & 48,00 & 160,00 \\
\cline { 2 - 7 } & Erkek & 92 & 136,63 & 22,34 & 70,00 & 160,00 \\
\cline { 2 - 7 } & Toplam & 216 & 135,99 & 22,78 & 48,00 & 160,00 \\
\hline \multirow{2}{*}{$\begin{array}{c}\text { Düzenli Spor Yapma } \\
\text { Durumu }\end{array}$} & Evet & 91 & 138,83 & 22,37 & 56,00 & 160,00 \\
\cline { 2 - 7 } & Hayır & 125 & 133,92 & 22,95 & 48,00 & 160,00 \\
\cline { 2 - 7 } Bilede Engelli Birey & Toplam & 216 & 135,99 & 22,788 & 48,00 & 160,00 \\
\cline { 2 - 7 } \begin{tabular}{c} 
Bulunma Durumu \\
\cline { 2 - 7 }
\end{tabular} & Hayır & 18 & 138,66 & 25,12 & 73,00 & 160,00 \\
\cline { 2 - 7 } & Toplam & 216 & 135,75 & 22,61 & 48,00 & 160,00 \\
\hline \multirow{2}{*}{ Sınıf } & 2 & 50 & 128,30 & 28,66 & 48,00 & 160,00 \\
\hline & 3 & 38 & 136,86 & 22,95 & 64,00 & 160,00 \\
\hline & 4 & 35 & 141,71 & 17,57 & 92,00 & 160,00 \\
\hline & 5 & 28 & 141,78 & 15,13 & 115,00 & 160,00 \\
\hline & 6 & 27 & 145,48 & 15,42 & 119,00 & 160,00 \\
\hline & Toplam & 216 & 135,99 & 22,78 & 48,00 & 160,00 \\
\hline
\end{tabular}

Tablo 2'ye göre araştırma kapsamına alınan tıp fakültesi öğrencilerinin cinsiyet değişkenine göre farkındalık puan ortalamalarına bakıldığında, kadın öğrencilerin farkındalık puan ortalaması $(\bar{x} 135,5242)$ iken erkek öğrencilerin farkındalık puan ortalaması $(\overline{\mathrm{x}} 136,6304)$ 'tür. Ayrıca genel farkındalık puan ortalaması ise ( 135,9954$)$ 'tür. Düzenli spor yapma değişkenine göre, düzenli spor yapan öğrencilerin farkındalık puan ortalaması $(\bar{x} 138,8352)$ iken düzenli spor yapmayan öğrencilerin farkındalık puan ortalaması ( $\bar{x} 133,9280)$ 'dir. Ailede/akrabada engelli birey bulunması değişkenine göre, ailesinde/akrabasında engelli birey bulunan öğrencilerin farkındalık puan ortalaması $(\bar{x} 138,6667)$ iken ailesinde/akrabasında engelli birey bulunmayan öğrencilerin farkındalık puan ortalaması ( $\bar{x} 135,7525)$ 'tir. Sınıf değişkenine göre, 1. sınıf öğrencilerinin farkındalık puan ortalaması ( $\bar{x} 128,3000), 2$. sınıf öğrencilerinin ( $\bar{x} 128,9737), 3$. sınıf öğrencilerinin ( $\bar{x} 136,8684), 4$. sınıf öğrencilerinin $(\bar{x} 141,7143), 5$. sınıf öğrencilerinin $(\bar{x} 141,7857), 6$. sınıf öğrencilerinin ise $(\bar{x} 145,4815)$ 'tir. 
Tablo 3. Araştırmaya Katılan Öğrencilerin Zihinsel Engelli Bireylerde Sporun Etkilerine Yönelik Farkındalık Ölçeği Puanlarının, Cinsiyet, Düzenli Spor Yapma Durumu ve Ailede Engelli Birey Bulunması Değişkenlerine Göre Farklılığı için MannWhitney U Testi

\begin{tabular}{|c|c|c|c|c|c|c|c|}
\hline Değişken & Seçenek & $\mathbf{N}$ & $\begin{array}{c}\text { Sıra } \\
\text { Ortalaması }\end{array}$ & $\begin{array}{l}\text { Sıralar } \\
\text { Toplamı }\end{array}$ & $\begin{array}{c}\text { Mann } \\
\text { Whitney U }\end{array}$ & Z & $\mathbf{P}$ \\
\hline \multirow{2}{*}{ Cinsiyet } & Kadın & 124 & 107,60 & 13343,00 & \multirow{2}{*}{5593,000} & \multirow{2}{*}{,- 245} & \multirow{2}{*}{,806 } \\
\hline & Erkek & 92 & 109,71 & 10093,00 & & & \\
\hline \multirow{2}{*}{$\begin{array}{l}\text { Düzenli Spor } \\
\text { Yapma Durumu }\end{array}$} & Evet & 91 & 117,11 & 10657,00 & \multirow{2}{*}{4904,000} & \multirow{2}{*}{$-1,734$} & \multirow{2}{*}{,083 } \\
\hline & Hayır & 125 & 102,23 & 12779,00 & & & \\
\hline \multirow{2}{*}{$\begin{array}{c}\text { Ailede Engelli } \\
\text { Birey Bulunma } \\
\text { Durumu }\end{array}$} & Evet & 18 & 122,83 & 2211,00 & \multirow{2}{*}{1524,000} & \multirow{2}{*}{$-1,020$} & \multirow[b]{2}{*}{,308 } \\
\hline & Hayır & 198 & 107,20 & 21225,00 & & & \\
\hline
\end{tabular}

Tablo 3'e göre araştırma kapsamına alınan tıp fakültesi öğrencilerinin ZEBSEYFÖ puanlarında, cinsiyet, düzenli spor yapma durumu ve ailede engelli birey bulunma durumu değişkenlerine göre anlamlı bir farklılık yoktur. Ancak erkek öğrencilerin farkındalık düzeyleri, kadın öğrencilerin farkındalık düzeyine göre ( $Z=$ ,245, $p=, 806>\alpha=, 05$ ); düzenli spor yapan öğrencilerin farkındalık düzeyleri, düzenli spor yapmayan öğrencilerin farkındalık düzeyine göre $(Z=-1,734, p=, 083>\alpha=, 05)$; ailesinde engelli birey bulunan öğrencilerin farkındalık düzeyleri, ailesinde engelli birey bulunmayan öğrencilerin farkındalık düzeyine göre daha yüksektir $(Z=-1,020$, $p=, 308>a=, 05)$.

Tablo 4. Araştırmaya Katılan Öğrencilerin Zihinsel Engelli Bireylerde Sporun Etkilerine Yönelik Farkındalık Ölçeği (ZEBSEYFÖ) Puanlarının, Sınıf Değişkenine Göre Farklıı̆ı için Kruskal-Wallis Testi

\begin{tabular}{|c|c|c|c|c|c|}
\hline & Sinıf & $\mathbf{N}$ & Sıra Ortalaması & $x^{2}$ & $\mathbf{p}$ \\
\hline \multirow{6}{*}{ Farkındalık Puanı } & 1 & 50 & 92,80 & \multirow{6}{*}{14,84} & \multirow{6}{*}{, $01^{\star}$} \\
\hline & 2 & 38 & 86,49 & & \\
\hline & 3 & 38 & 113,12 & & \\
\hline & 4 & 35 & 122,00 & & \\
\hline & 5 & 28 & 119,68 & & \\
\hline & 6 & 27 & 132,96 & & \\
\hline
\end{tabular}

Tablo 4'e göre araştırma kapsamına alınan tıp fakültesi öğrencilerinin ZEBSEYFÖ puanlarında, sınıf değişkenine göre anlamlı bir farklıık görülmektedir. 6 . sınıfta bulunan öğrencilerin farkındalık düzeyi en yüksek, 2. sınıfta bulunan öğrencilerin farkındalık düzeyi ise en düşüktür (Ki-Kare $=14,846, p=, 011<\alpha=, 05$ ). 


\section{Tartışma ve Sonuç}

Bu bölümde araştırmaya katılan doktor adaylarının zihinsel yetersizliği olan bireylerde sporun etkilerine yönelik farkındalıklarının ne düzeyde olduğu; "cinsiyet, sınıf, düzenli spor yapma durumu, akraba/ailede engelli birey olma durumu ve eğer varsa engel türleri” değişkenlerine göre engellilere yönelik farkındalık ve tutumlarının değişip değişmediğinin belirlenmesi amaçlanmaktadır. Buna göre, katılımcılardan elde edilen bulgular bu bölümde tartışılmış, yorumlanmış ve mevcut araştırma literatürdeki araştırma bulgularıyla desteklenmeye çalışılmıştır.

Araştırma bulgularına göre; araştırmaya katılan tıp fakültesi öğrencilerinin zihinsel engelli bireylerde sporun etkilerine yönelik farkındalık düzeylerinin cinsiyet değişkeni açısından anlamlı bir farklılık göstermediği tespit edilmiştir. Bu durumun, kadın ve erkek bireylerin toplumda eşit rolleri paylaşıp, benzer mesleki farkındalıklara ve bilgi düzeyine sahip olmaları ve çalışma koşullarının benzer olmasından kaynaklı olduğu söylenebilir. Zengin, Kaya ve Bezci (2016)'nin araştırmasında da spor eğitimi alan üniversite öğrencilerinin farkındalıklarında cinsiyete göre farklılaşma olmadığı belirlenmiştir. İlgili alan yazında, araştırma bulgularına paralellik gösteren çalışmalar mevcuttur (Tervo ve ark., 2002; Özyürek, 2006; Çolak ve Çetin, 2014; Yaralı, 2015, Esentürk ve ark., 2015, Sural ve ark., 2017). Araştırma bulgularından farklı olarak, kadın öğrencilerin, erkek öğrencilere göre farkındalıklarının anlamlı düzeyde yüksek olduğu tespit edilen araştırmalar da bulunmaktadır (Akyıldız, 2017; Gökçe ve ark., 2016; Kırımoğlu ve ark., 2016; Kırımoğlu ve ark., 2016; Yıldırım Sarı ve ark., 2010).

Araştırmada tıp fakültesi öğrencilerinin düzenli spor yapma durumuna göre zihinsel engelli bireylerde sporun etkilerine yönelik farkındalık düzeyleri incelenmiştir. Buna göre, düzenli spor yapma durumu ile tıp fakültesi öğrencilerinin zihinsel engelli bireylerde sporun etkilerine yönelik farkındalık düzeylerinde anlamlı bir farklılık tespit edilmemiş; düzenli spor yapan öğrencilerin farkındalık düzeylerinin daha yüksek olduğu saptanmıştır. Elde edilen bu sonuç için, günümüzde bireylerin sporun sosyal, zihinsel, psikomotor, duygusal gelişime katkılarına yönelik çeşitli yayın ve yayımlarla bilinçlenmesi, sporun rehabilite edici özelliğinin yanı sıra sağlık için de vazgeçilmez unsur olduğunun kabul edilmesi ile sağlık ve rehabilitasyon hizmetleri kapsamında çeşitli derslerle öğrencilerin bilgilendirilmesinin etkili olduğu düşünülebilir. Nitekim üniversite öğrencilerinin özel eğitim ile ilgili ders almalarının engellilere yönelik farkındalık ve tutumlarını arttırdığı çeşitli araştırmalarda tespit edilmiştir (Akbuğa ve Gürsel, 2007; Alptekin ve Vural Batık, 2013; Gürsel, 2006; Kırımoğlu ve ark., 2016; 
Özyürek, 2006; Sezer, 2012; Şahin ve Güldenoğlu, 2013). Literatür incelendiğinde, Zengin, Kaya ve Bezci (2016)'nin “Antrenörlük eğitimi ve spor yöneticiliği bölümü öğrencilerinin engellilerde sporun etkileri konusundaki farkındalık düzeylerinin incelenmesi” isimli araştırması, mevcut araştırma bulgularıyla benzer sonuç göstermektedir. Araştırma bulgularının aksine Kırımoğlu ve ark. (2016)'nın araştırmasında, düzenli spor yapan ve sedanter öğrencilerin farkındalık düzeylerinde anlamlı farklıık tespit etmiştir. Buna göre, düzenli spor yapma alışkanlığı bulunan öğrencilerin engellilerde sporun etkileri konusundaki farkındalık düzeylerinin düzenli spor yapmayan öğrencilere kıyasla daha yüksek olduğunu tespit edilmiştir.

Araştırmanın bir başka bulgusunda, araştırmaya katılan tıp fakültesi öğrencilerinin zihinsel engelli bireylerde sporun etkilerine yönelik farkındalık düzeylerinin ailede/akrabada engelli birey bulunup bulunmama değişkenine göre anlamlı bir farklıık göstermediği tespit edilmiştir. Bu duruma neden olarak, çağımızda engelli bireylerin toplum içindeki yerini alması, basın ve yayında ilgili haberlerde görülmesi, kaynaştırma eğitimlerinin artması ve hayatın birçok noktasında istemliistemsiz farkında olmaksızın onlarla ilişki kurulmasından kaynaklandığı söylenebilir. Bulgular çalışmayı destekleyici nitelikte olup gruplar arası farklılık görülmemesinin diğer bir nedeni, araştırmaya katılan öğrenciler arasındaki eşit olmayan dağılımla açıklanabilir. Mevcut araştırma bulgusuna paralel olarak, engelli biriyle yaşayan veya engelli yakını olan katıııcılar ile yakın çevresinde engelli birey olmayan katılımcıların farkındalık düzeylerinin benzer olduğunu tespit eden araştırmalar bulunmaktadır (Şahin ve Bekir, 2016; Kııımoğlu ve ark., 2016; Zengin ve ark., 2016; Yıldırım Sarı ve ark., 2010). Alan yazında, araşııma bulgularından farklı olarak, engelli yakını olan bireylerin engellilere yönelik tutumlarının daha olumlu olduğunu gösteren çalışmalar da bulunmaktadır (Thompson ve ark., 2003; Horner Johnson ve ark., 2002; Sezer, 2012; Çolak ve Çetin, 2014; Gülünay ve ark., 2017).

Araştırmaya katılan 2. sınıf tıp fakültesi öğrencilerinin 6. sınıf tıp fakültesi öğrencilerine göre zihinsel yetersizliği olan bireylerde sporun etkilerine yönelik farkındalık düzeyleri incelendiğinde, 2. sınıf öğrencilerinin 6. sınıf öğrencilerinden anlamlı düzeyde düşük farkındalığa sahip oldukları tespit edilmiştir. Bu bulgular doğrultusunda tıp fakültesi öğrencilerinin, 6 yıllık öğrenimleri süresince her yıl bilgi birikimlerinin artması ile doğru orantılı olarak farkındalık düzeylerinin de artış gösterdiği düşünülebilir. Literatürde öğrencilerin engelli bireylere yönelik tutumlarının sınıf düzeyine göre farklıık gösterdiğini belirten çalışmaların yanında (Akyıldız, 2017; 
Kargın ve Baydık, 2002; Thompson, Emrich ve Moore, 2003) engellilere yönelik tutumların sınıf düzeyine göre değişmediğini gösteren çalışmalar da (Sarı Yıldırım, Bektaş ve Altıparmak, 2010; Şahin ve Bekir, 2016) bulunmaktadır.

Sonuç olarak araştırmaya katılan doktor adaylarının zihinsel engelli bireylerde sporun etkilerine yönelik farkındalık düzeylerinin cinsiyet, düzenli spor yapıp yapmama durumu, ailede/akrabada engelli birey bulunup bulunmama değişkenlerine göre istatistiksel anlamda bir farklılık bulunmazken; sınıf değişkenine göre anlamlı bir farklıık tespit edilmiştir. Ayrıca öğrencilerin farkındalık puan aralıkları değerlendirildiğinde cinsiyet, düzenli spor yapıp yapmama durumu, ailede/akrabada engelli birey bulunup bulunmama durumu ve sınıf değişkenleri açısından yüksek düzeyde farkındalığa sahip oldukları bulunmuş olup sınıf düzeylerine göre farkındalık puanlarının artış gösterdiği saptanmıştır. Bulgular neticesinde farkındalığın yüksek düzeyde bulunması, tıp fakültesi öğrencilerinin almış oldukları eğitimle açıklanabilir. Nitekim gerek örgün gerekse yaygın eğitimle toplumlara bilgilendirme yoluyla farkındalık kazandırıması mümkündür. Bu nedenle doktor adaylarının düzenli spor yapmaya teşvik edilmesinin, eğitim programları içinde beden eğitimi ve spor derslerinin çoğaltılarak engelli bireyler üzerindeki etkilerine yönelik bilgi verilmesinin farkındalığın arttıııması açısından daha etkili olacağı düşünülmektedir. Alan yazınındaki çeşitli tutum ve farkındalık çalışmaları da bu bulguları destekleyici mahiyettedir (Kunduracılar ve ark., 2012; Kırımoğlu ve ark., 2016; Akbuğa ve Gürsel, 2007; Gürsul ve Tüzün, 2008).

Elde edilen bulgular ve sonuç kapsamında;

- Ebeveynlerin ardından gözlem, araştırma ve değerlendirmelerde bulunan doktorların yetiştirilmesinde beden eğitimi ve spor eğitiminin zorunlu olarak tıp fakültelerinde yer alması,

- Hali hazırda tıp fakültesi lisans eğitimi programlarında yer alan seçmeli beden eğitimi derslerinin içeriğinin düzenlenmesi ve yetersizliği olan bireylerde sporun etkilerine yönelik eğitim verilmesi,

- Hizmet içi eğitim programlarında yetersizliği bulunan bireyler üzerinde sporun psikolojik, sosyal, bilişsel ve psikomotor alanlarındaki etkilerine yönelik bilgilendirmeler (seminer, panel vb.) yapılması,

- Doktorlara, doktor adaylarına ve ilgili sağlık personeline düzenli spor yapma hususunda zaman ayırılması ve bu konuda teşvik edilmeleri önerilmektedir. 


\section{Kaynaklar}

Akbuğa, B. ve Gürsel, F. (2007). Bilgilendirme yoluyla beden eğitimi ve spor yüksekokulu öğrencilerinin engelli bireye yönelik değişen tutumları. Spormetre Beden Eğitimi ve Spor Bilimleri Dergisi, V(1), 5-8.

Akyıldız, S. (2017). Öğretmen adaylarının engelli bireylere yönelik tutumlarının incelenmesi. Sosyal Politika Çalışmaları Dergisi, 17(39), 141-175.

Alptekin, S. ve Batık, M. V. (2013). Özel eğitim bölümü öğrencilerinin yetersizlikten etkilenmiş kişilere yönelik tutumlarına özel eğitim dersinin etkisi. e-Uluslararası Eğitim Araştırmaları Dergisi, 4(4), 18-34.

Çavdar, B. (2011). Öğretilebilir zihinsel engelli öğrencilerde beden eğitimi ve spor aktivitelerinin toplumsallaşma düzeylerine etkisi. Yüksek Lisans Tezi, Ege Üniversitesi Sağlık Bilimleri Enstitüsü, İzmir.

Çolak, M. ve Çetin, C. (2014). Öğretmenlerin engelliliğe yönelik tutumları üzerine bir araştırma. Dokuz Eylül Üniversitesi İktisadi ve İdari Bilimler Fakültesi Dergisi, 29(1), 191-211.

Esentürk, O. K., Koç, Y., Yarımkaya, E. ve İlhan E. L. (2015). University students awareness levels on the effects of sport in mentally retarded individuals, III. International Exercıse snd Sport Psychology Congress, İstanbul, Turkey, 100.

Filazoğlu, G., Kırımoğlu, H., Öz, A. Ş. ve İıhan, E. L. (2015). The effects of physical education and sports on the self-concept of the children with mild mental disabilities, International Journal of Science Culture and Sport, 3(3), 55-72.

Gökçe, A., Güneş, G. ve Çelik-Seyitoğlu, D. (2016). İnönü üniversitesi tıp fakültesi öğrencilerinin engellilere yönelik tutum ve davranışları. Medicine Science, 5(2), 351-362. doi: 10.5455/medscience.2015.04.8381

Gülünay, Y. İ., Kayışoğlu, N. B. ve İlhan E. L. (2017). Beden eğitimi öğretmeni adaylarının zihinsel engelli çocuklara yönelik tutumlarının çeşitli değişkenlere göre incelenmesi, 15. Uluslararası Spor Bilimleri Kongresi Bildiri Kitabı, 1540.

Gürsel, F. (2006). Engelliler için beden eğitimi ve spor dersi'nin öğrencilerin engellilere yönelik tutumlarına etkisi. Hacettepe Üniversitesi Eğitim Fakültesi Dergisi, 31(31), 67- 73.

Gürsul, F. ve Tüzün, H. (2008). Öğretmen adaylarının görme ve işitme engelli bireylere karşı farkındalıklarının problem-tabanlı öğrenme yaklaşımı kullanılarak arttırılması. Bilişim'08 Bildiriler Kitabı, Ankara, Turkey, 7-10. 
Güvendi, B. ve Illhan E. L. (2017). Effects of adapted physical activity applied on intellectual disability students toward level of emotional adjustment, selfmanagingand the socialization: Parent and teacher interactive research, International Journal of Human Sciences, 14(4), 3880-3894.

Horner-Johnson, W., Keys, C., Henry, D., Yamaki, K., Oi, F., Watanabe, K. et al. (2002). Attitudes of japanese students toward people with intellectual disability. Journal of Intellectual Disability Research, 46(5), 365-378.

İlhan, L. (2008). Eğitilebilir zihinsel engelli çocuklarda beden eğitimi ve sporun sosyalleşme düzeylerine etkisi, Kastamonu Eğitim Fakültesi Dergisi, 16(1), 315324.

İlhan, L. (2008). Zihinsel engelli çocuklar için beden eğitimi ve sporun genel gelişim süreçleri açısından önemi. Çağdaş Eğitim Dergisi, 33(350), 17-24.

İlhan, L. (2009). Zihinsel engelli çocuğu olan anne-babaların çocuklarının özel eğitimleri sürecinde beden eğitimi ve spor etkinliklerine yaklaşımlarının değerlendirilmesi. Niğde Üniversitesi Beden Eğitimi ve Spor Bilimleri Dergisi, 3(1), 38-48.

İlhan, E. L. ve Esentürk, O. K. (2015). Zihinsel engelli bireylerde sporun etkilerine yönelik farkındalık ölçeği (zebseyfö) geliştirme çalışması. CBÜ Beden Eğitimi ve Spor Bilimleri Dergisi, 9(1), 19-36.

Karasar, N. (2009). Bilimsel araştırma yöntemi, Ankara: Nobel Yayın Dağıtım.

Kargın, T. ve Baydık, B. (2002). Kaynaştırma ortamındaki işiten öğrencilerin işitme engelli akranlarına yönelik tutumlarının çeşitli değişkenlere göre incelenmesi. Ankara Üniversitesi Eğitim Bilimleri Fakültesi Özel Eğitim Dergisi, 3(2), 27-39.

Kayıhan, H., Tekin Dal, B., Irmak, A. ve Akyürek, G. (2013). Farkındalık ve ulaşılabilirlik rehberi, Ankara: Hacettepe Üniversitesi Basımevi.

Kırımoğlu, H., Yılmaz, A., Soyer, F., Beyleroğlu, M. ve İlhan, E. L. (2016). Zihinsel engelli bireylerde sporun etkilerine yönelik farkındalık: beden eğitimi öğretmen adayları üzerine bir araştırma. Niğde Üniversitesi Beden Eğitimi ve Spor Bilimleri Dergisi, 10(1), 80-88.

Kırımoğlu, H., Esentürk, O., İlhan, E. L., Yılmaz, A. ve Kaynak, K. (2016). İlköğretim, özel eğitim ve rehabilitasyon merkezi öğretmenleri ile beden eğitimi ve spor öğretmen adaylarının zihinsel engelli bireylerin fiziksel egzersize katılımlarının etkilerine yönelik farkındalık düzeylerinin incelenmesi. Manas Sosyal Araştırmalar Dergisi, 5(4), 231-244. 
Koparan, Ş. (2003). Özel intiyaçları olan çocuklarda spor. Uludağ Üniversitesi Eğitim Fakültesi Dergisi, 17(1), 153-160.

Kunduracılar, Z., Akbaş, E., Büyükuysal, Ç., Biçki, D. ve Erdem, E. U. (2012). Fizyoterapi ve rehabilitasyon bölümü öğrencilerinde mesleki farkındalığın değerlendirilmesi. Journal of Higher Education and Science, 2(3), 186-192. doi: 10.5961/jhes.2012.049

Özyürek, M. (2006). Engellilere yönelik tutumların değiştirilmesi, Ankara: Kök Yayıncilık.

Sezer, F. (2012). Engelli bireylere karşı olumlu tutum geliştirmeye yönelik önleyici rehberlik çalışması; deneysel bir uygulama. e-Journal of New World Sciences Academy, 7(1), 16-26.

Sural, V., İlhan E. L, Esentürk O. K. (2017). Özel gereksinimli çocuklarla çalışan antrenörlerin iş doyum düzeylerinin incelenmesi, 3. Uluslararası Engellilerde Beden Eğitim ve Spor Kongresi Kongre Kitabı, Konya, Türkiye, 130.

Şahin, F. ve Güldenoğlu, B. (2013). Engelliler konusunda verilen eğitim programının engellilere yönelik tutumlar üzerindeki etkisi. Amasya Üniversitesi Eğitim Fakültesi Dergisi, 2(1), 214-239.

Şahin, H. ve Bekir, H. (2016). Üniversite öğrencilerinin engellilere yönelik tutumlarının belirlenmesi. Türkiye Sosyal Araştırmalar Dergisi, 3, 767-779.

Tervo, R. C., Azuma, S., Palmer, G. and Redinius, P. (2002). Medical Students' Attitudes Toward Persons With Disability: A Comparative Study. Archives of Physical Medicine And Rehabilitation, 83(11), 1537-1542. doi:10.1053/apmr.2002.34620

Thompson, T. L. C., Emrich, K. ve Moore, G. (2003). The effect of curriculum on the attitudes of nursing students toward disability. Rehabilitation Nursing, 28(1), 2730.

Turan-Kavradım, S. ve Canlı-Özer, Z. (2014). Kanser tanıSı alan hastalarda umut. Psikiyatride Güncel Yaklaşımlar, 6(2), 154-164.

Yaralı, D. (2015). Öğretmen adaylarının özel gereksinimli bireylere yönelik tutumlarının bazı değişkenler açısından incelenmesi. Erzincan Üniversitesi Eğitim Fakültesi Dergisi, 17(2), 431-455.

Yetim, A. (2011). Sosyoloji ve spor, Ankara: Berikan.

Yıldırım-Sarı, H., Bektaş, M. ve Altıparmak, S. (2010). Hemşirelik öğrencilerinin engellilere yönelik tutumlarının belirlenmesi. Yeni Tıp Dergisi, 27, 80-83. 
Zengin, S., Kaya, E. ve Bezci, Ş. (2016). Antrenörlük eğitimi ve spor yöneticiliği bölümü öğrencilerinin engellilerde sporun etkileri konusundaki farkındalık düzeylerinin incelenmesi. Uluslararası Multidisipliner Akademik Araştırmalar Dergisi, 3(2), 45-56.

\section{İnternet Kaynakları}

http://siteresources.worldbank.org/TURKEYINTURKISHEXTN/Resources/455687-

1328710754698/YoneticiOzeti.pdf adresinden 15 Mayıs 2017 tarihinde erişilmiştir.

https://eyh.aile.gov.tr/uploads/pages/engelli-ve-yasli-bireylere-iliskin-istatistiki-

bilgiler/2018-yili-nisan-ayi-bultenini-bu-baglantiyi-kullanarak-indirebilirsiniz.pdf adresinden 26 Kasım 2018 tarihinde erişilmiştir. 